\title{
Perfusion techniques in minimally invasive setting
}

\author{
Yuri Ganushchak, Peyman Sardari Nia \\ Department of Cardiothoracic Surgery, Maastricht University Medical Centre, Maastricht, The Netherland \\ Contributions: (I) Conception and design: Y Ganushchak; (II) Administrative support: P Sardari Nia; (III) Provision of study materials or patients: \\ None; (IV) Collection and assembly of data: All authors; (V) Data analysis and interpretation: None; (VI) Manuscript writing: All authors; (VII) Final \\ approval of manuscript: All authors. \\ Correspondence to: Yuri Ganushchak, MD, PhD. Department of Cardiothoracic Surgery, Section Extra-Corporeal Circulation, Maastricht University \\ Medical Center, PO box 5800, 6202 AZ Maastricht, The Netherlands. Email: y.ganushchak@mumc.nl.
}

\begin{abstract}
Further development and improvement of extracorporeal circulation (ECC) is paramount for the success in 'minimally invasive cardiac surgery'. This requires advance in underling technology as well as a special mindset and a high level of situation awareness of perfusionist in order to balance safe perfusion and providing optimal conditions for the surgeon to operate. The necessity of this balance influences all stages of preparing and performing the surgical intervention and involve selection of equipment, methods and level of control of patient's homeostasis and timely compensation for necessary deviations. There are examples presented: selection of heart-lung machine set and cannulation, and a choice of the method of preventing effective heart contraction during minimal invasive cardiac surgery. These examples demonstrate that decisions in minimal invasive setting is often a 'maze' choice with impact at all stages of intervention and all specialists involved. The team approach that coordinates efforts of the surgeon, anesthesiologist, perfusionist, and nurses is paramount to achieve the best clinical outcomes.
\end{abstract}

Keywords: Cardiac surgery; extracorporeal circulation (ECC); perfusionist; patient safety

Received: 16 July 2018; Accepted: 07 December 2018; Published: 21 December 2018.

doi: 10.21037 /jovs.2018.12.04

View this article at: http://dx.doi.org/10.21037/jovs.2018.12.04

The current social developments stimulate introduction and fast expansion of 'minimally invasive cardiac surgery' (1). The minimizing of surgical trauma involves changing in access to the heart and requires using of special instruments and techniques. This often leads to an increase of the duration of cardiopulmonary bypass as well as an increase of aorta occlusion time, which could lessen the physiologic benefit of the procedure. In this situation, extracorporeal circulation (ECC) is becoming an important determining factor. ECC is a highly sophisticated process based on information obtained from sources such as ECC indicators, hemodynamic parameters, surgeons, an operating field, a scrub nurse, surgical instruments, and monitors (2). It is apparent that effective work in an increase complex environment requires a special mindset and a high level of situation awareness. The perfusionist must be ready to adapt ECC according to alterations in patient's condition as well as to changes in the operating field, in order to balance safe perfusion and providing optimal conditions for the surgeon to operate.

The necessity of this balance influences all stages of preparing and performing the surgical intervention, like for example selecting the ECC set for the heart-lung machine. Thus, minimizing surgical trauma also requires minimalizing the ECC circuit, where augmented venous drainage is an important feature. Two methods of augmentation of venous drainage exist, using three types of ECC sets, i.e., (I) open set with vacuum assisted venous drainage (VAVD); (II) closed system with kinetic assisted venous drainage (KAVD); and (III) minimized extracorporeal circuit (miECC). Each type has its benefits and drawbacks, which are discussed below.

The open set with VAVD is based on the contemporary hard-shell open reservoir with a low priming and dynamic volume (3) that is considered as an important factor for lessening deleterious effects of ECC (4). Additionally, open systems with VAVD are recognized to be easy to operate 
and therefore considered beneficial. The open systems with VAVD are the most robust and flexible systems in use. However, they have their snags. ECC with open systems mean continuous exposure to a large and complex surface that contains defoaming sponges and antifoam agents. The use of open-systems in comparison to close-systems is shown to be aggravation of the complement pathway activation, release of polymorphoneculocytes elastase, fibrin degradation products, thromboxane $\mathrm{B} 2$, and larger shed blood loss (5-8). In addition, open systems with VAVD are associated with an increase transmission of gaseous microemboli (9-13), venous line chattering (14), increased arterial to venous shunt in the circuit (15), and haemolysis $(16,17)$. Moreover, numerous case reports and anecdotes of catastrophic events are described while using VAVD, such as overpressuring of the venous reservoir (9-13) or gas bubbles transgression in membrane oxygenators (18).

A second method to augment drainage uses a centrifugal pump in the venous line before the venous reservoir, also referred to as KAVD. Using KAVD as a closed system in combination with a soft-shell reservoir excludes the negative effects of an open system and complications of VAVD with a hard-shell venous reservoir. However, as well as with VAVD the augmented subatmospheric pressure in the venous line during KAVD, increases the chance for air entering the circulation, venous line chattering, and possible haemolysis (19).

Despite the fact that data describing the resistance to air in the venous line of open systems and closed systems are contradictory, air in venous line of both systems will pass to the arterial side with resultant transmission of gaseous micro-emboli (20). The relatively higher priming volume of the closed systems in comparison to the open systems, as well as the necessity of controlling an additional pump could be named as disadvantages of the closed system with KAVD. Furthermore, incorporation of an additional pump increases the system complexity and consequently the probability of increased user error (21).

miECCs s can be seen as a further development of the KAVD when a single centrifugal pump augments venous drainage and returns blood to the patient at the same time. In a recently published position paper from the Minimal invasive Extra-Corporeal Technologies international Society, it is stated that miECC has to be considered as part of minimally invasive cardiac surgery, which could maximize clinical benefits further improving patient outcomes (22). Operating miECC in combination with contemporary trends for controlling physiological parameters facilitates development of a "physiologically based" surgery (23-25). The beneficial effects miECC on morbidity and mortality are related to reduction of haemodilution, mediastinal bleeding, and inflammatory response, as well as the reduced blood transfusion requirements (22,26-32).

Evident benefits of minimized cardiopulmonary bypass (CPB) systems, however, do not come without consequences. The major limitation of these systems is absence of a venous reservoir, which in turn requires special volume management. According to Anastasiadis et al. teamwork is paramount as well as a learning curve involving at least 50 successful interventions in order to gain optimal results (33). Further, absence of a venous reservoir generates safety concerns of the circuit in cases of air entrainment or significant blood volume loss or sudden change of the surgery plan $(23,34,35)$. Attempts to increase safety of miECC systems often lead to proliferation of system complexity, e.g., modification of the Medtronic Resting Heart System described by Fernandes et al. (36), or the modular AHEPA circuit design (23). Rise in complexity of a system could increase the chance for user and/or technical errors (21). Taking this in account, we developed a versatile minimized system that is in fact a KAVD open system where the hard-shell reservoir is bypassed using a so-called Better-Bladder that provides venous line compliance during augmented drainage, facilitating a rather simple and robust system (35).

The other, close related to the heart-lung machine set, question is the selection of cannulas and cannulation sites. The importance of these questions is reinforced by the obligate requirement of stable $\mathrm{CPB}$ and bloodless exposure of the valve for the success of MICS (37). Therefore, the choice of cannulation site and type of cannula should be done for each patient based on patient risk profile and with a backup plan. There are a substantial number of publications discussing benefits and disadvantages of numerous cannulation sites (37-45). Although extracorporeal circuit components can be considered harmless if used according to prescription, extensive cellular damage can be caused by the way the extracorporeal circuit is composed and managed (46). The cannulas as a narrowest part of heart-lung machine set may have great impact at the blood trauma. For any cannula exists a point beyond which the flow becomes at first disturbed and then, at increasing flow rates, it becomes turbulent. Although, the underlying mechanisms of turbulence induced trauma are not clear, it has been shown that at identical shear stress, turbulent flow produces far more blood trauma than laminar flow (47). In turn, haemolysis appears to be an important contributor to postoperative kidney injury and intestinal 
mucosal damage, potentially by limiting no-bioavailability (48). In addition, too small diameter of venous cannula will entail increased subatmospheric venous line pressures and causes direct damage of red cells (16) and gas emboli formation denovo $(35,49,50)$.

The challenge of proper cannulas selection amplified by most commonly used in the medical industry the French (Fr) (51) scale which describes only the outer diameter of catheter. Some information can be acquired from the flowpressure curves presented by industry. However, these flowpressure curves are based on the tests with water at room temperature. The prediction of blood flow through complex shapes of cannulas can only be done using computational fluid dynamics models which are complex and only possible using commercial packages (52). Even using of simplified methods, like 'M-number' $(53,54)$ or methods based at the concept of dynamic similarity $(55-58)$ is problematic. Unfortunately, there is not much attention in surgical world paid to the hydrodynamic, and available information can be misleading. For example, article "Systemic venous drainage: can we help Newton?" by Corno (19) contains 2 error, starting from inappropriate application of Poiseuille equation for describing flow in cannulas till a simple algebraic error.

So, low awareness in hydrodynamic and physiological consequences of using small diameter cannulas as well as fear of possible complications makes selection of proper cannulas rather challenging. However, in practice, femoral cannulation after a short learning curve has a low risk of complications (40,43). Furthermore, preoperative computed tomography angiogram or magnetic resonance angiography aids to predict hitches of cannulation and perfusion, and consequently prevent vascular complications $(59,60)$.

The surgical choices like cannulation sites, type of arterial and venous cannulas is thus a complex task involving balance of surgical requirements, experience, and demand of minimizing possible harmful effects of ECC. Similar accounts for situations when the arts of extracorporeal technology are challenged by the necessity of balance between safe perfusion and optimal conditions for surgery, which include not only the components of circuit but also the long list of interrelated physiological parameters that are under the control of the perfusionist during CPB. The most important parameters are mean arterial blood pressure, systemic bypass flow rates, oxygen delivery, haemodilution and haematocrit values, systemic temperatures, pulsatile and non-pulsatile perfusion, and blood gas management $(8,61)$, all to preserve homeostasis.

The way of preventing effective heart contraction during the minimal invasive surgical intervention is another example of laborious choice which affect not only the course of surgery, but also ECC.

Such easy answered question during open heart surgery with median sternotomy as myocardial protection becomes a multivariable selection challenge in minimally invasive approach. There are several methods to prevent effective heart contraction during minimal invasive cardiac surgery, which include infusion of a cardioplegic solution after external or endovascular aortic occlusion, induced fibrillation (62-66), and empty-heart beating described by several authors $(67,68)$. The first three methods are in use in our centre.

The mild hypothermia is used in case of external crossclamp of aorta, mean arterial pressure $(70-90 \mathrm{mmHg})$ and blood flow $\left(2.4-2.6 \mathrm{~L} \cdot \mathrm{min}^{-1} \cdot \mathrm{m}^{-2}\right)$ were controlled according to the patient's requirements.

Different perfusion technique required during surgery with endovascular aortic occlusion. The central body temperature decreased to $30{ }^{\circ} \mathrm{C}$. This allows to diminish blood flow till $1.9 \mathrm{~L} \cdot \mathrm{min}^{-1} \cdot \mathrm{m}^{-2}$. Careful control of arterial pressure is essential $(50-60 \mathrm{mmHg})$ to prevent migration of balloon.

Artificial heart fibrillation can be used as a primarily choice or as forced measure due to aortic cross-clamp failure. With this approach the central body temperature decreased to $28{ }^{\circ} \mathrm{C}$. However, it is possible to maintain flow close to $2.4 \mathrm{~L} \cdot \mathrm{min}^{-1} \cdot \mathrm{m}^{-2}$ and arterial pressure in range $70-90 \mathrm{mmHg}$. In case of grade 1 aortic insufficiency, it is necessary to keep lower mean arterial pressure with multiple decreasing of blood flow down to complete stop for a few minutes to provide conditions for surgeon to operate. Adequate reperfusion after each necessary stop of flow and hypothermia $28^{\circ} \mathrm{C}$ allows avoiding lactate accumulation and metabolic acidosis.

The two examples above demonstrate that decisions in cardiac surgery in particular in minimal invasive setting is often a 'maze' choices with impact at all stages of intervention and all specialists involved. The team approach that coordinates efforts of the surgeon, anaesthesiologist, perfusionist, and nurses is paramount to achieve the best clinical outcomes. The principle that the surgeon should automatically be the "captain of the ship" is no longer tenable. Today, every healthcare worker is held accountable for his or her own actions, and as mentioned, skills are not necessarily interchangeable between groups (69). The area of responsibility of perfusionist requires a high level of system awareness and fast decision making. System awareness is a function of individual information processing, innate abilities, 
experience, and training (70), but also includes explicit and tacit knowledge, and fast deductive reasoning (71). These together with communicative skills are the qualifications necessary to become a valuable member of a multidisciplinary and inter-professional cardiac team.

Conclusion. ECC is a highly sophisticated process which requires fast analysis of all available information and timely reaction in order to balance safe perfusion and providing optimal conditions for surgeon to operate. The dedicated team approach that coordinates efforts of the surgeon, anaesthesiologist, perfusionist, and nurses is paramount to achieve the best clinical outcomes.

\section{Acknowledgments}

Funding: None.

\section{Footnote}

Provenance and Peer Review: This article was commissioned by the editorial office, Fournal of Visualized Surgery for the series "Minimally Invasive Mitral Valve Surgery". The article has undergone external peer review.

Conflicts of Interest: Both authors have completed the ICMJE uniform disclosure form (available at http://dx.doi. org/10.21037/jovs.2018.12.04). The series "Minimally Invasive Mitral Valve Surgery" was commissioned by the editorial office without any funding or sponsorship. PSN served as the unpaid Guest Editor of the series. The authors have no other conflicts of interest to declare.

Ethical Statement: The authors are accountable for all aspects of the work in ensuring that questions related to the accuracy or integrity of any part of the work are appropriately investigated and resolved.

Open Access Statement: This is an Open Access article distributed in accordance with the Creative Commons Attribution-NonCommercial-NoDerivs 4.0 International License (CC BY-NC-ND 4.0), which permits the noncommercial replication and distribution of the article with the strict proviso that no changes or edits are made and the original work is properly cited (including links to both the formal publication through the relevant DOI and the license). See: https://creativecommons.org/licenses/by-nc-nd/4.0/.

\section{References}

1. Rosengart TK, Feldman T, Borger MA, et al. Percutaneous and minimally invasive valve procedures: a scientific statement from the American Heart Association Council on Cardiovascular Surgery and Anesthesia, Council on Clinical Cardiology, Functional Genomics and Translational Biology Interdisciplinary Working Group, and Quality of Care and Outcomes Research Interdisciplinary Working Group. Circulation 2008;117:1750-67.

2. Tomizawa Y, Aoki H, Suzuki S, et al. Eye-tracking analysis of skilled performance in clinical extracorporeal circulation. J Artif Organs 2012;15:146-57.

3. Durandy Y. Vacuum-assisted venous drainage, angel or demon: PRO? J Extra Corpor Technol 2013;45:122-7.

4. Pappalardo F, Corno C, Franco A, et al. Reduction of hemodilution in small adults undergoing open heart surgery: a prospective, randomized trial. Perfusion 2007;22:317-22.

5. Casalino S, Stelian E, Novelli E, et al. Reduced transfusion requirements with a closed cardiopulmonary bypass system. J Cardiovasc Surg (Torino) 2008;49:363-9.

6. Eisses MJ, Seidel K, Aldea GS, et al. Reducing hemostatic activation during cardiopulmonary bypass: a combined approach. Anesth Analg 2004;98:1208-16, table of contents.

7. Paparella D, Scrascia G, Rotunno C, et al. A biocompatible cardiopulmonary bypass strategy to reduce hemostatic and inflammatory alterations: a randomized controlled trial. J Cardiothorac Vasc Anesth 2012;26:557-62.

8. Murphy GS, Hessel EAn, Groom RC. Optimal perfusion during cardiopulmonary bypass: an evidence-based approach. Anesth Analg 2009;108:1394-417.

9. Gambino R, Searles B, Darling EM. Vacuum-Assisted Venous Drainage: A 2014 Safety Survey. J Extra Corpor Technol 2015;47:160-6.

10. Lou S, Ji B, Liu J, et al. Generation, detection and prevention of gaseous microemboli during cardiopulmonary bypass procedure. Int J Artif Organs 2011;34:1039-51.

11. Wang S, Baer L, Kunselman AR, et al. Delivery of gaseous microemboli with vacuum-assisted venous drainage during pulsatile and nonpulsatile perfusion in a simulated neonatal cardiopulmonary bypass model. ASAIO J 2008;54:416-22.

12. Wang S, Undar A. Vacuum-assisted venous drainage and gaseous microemboli in cardiopulmonary bypass. J Extra Corpor Technol 2008;40:249-56.

13. Willcox TW. Vacuum assist: angel or demon CON. J 
Extra Corpor Technol 2013;45:128-32.

14. Colangelo N, Torracca L, Lapenna E, et al. Vacuumassisted venous drainage in extrathoracic cardiopulmonary bypass management during minimally invasive cardiac surgery. Perfusion 2006;21:361-5.

15. Walker JL, Young HA, Lawson DS, et al. Optimizing venous drainage using an ultrasonic flow probe on the venous line. J Extra Corpor Technol 2011;43:157-61.

16. Mulholland JW, Massey W, Shelton JC. Investigation and quantification of the blood trauma caused by the combined dynamic forces experienced during cardiopulmonary bypass. Perfusion 2000;15:485-94.

17. Goksedef D, Omeroglu SN, Balkanay OO, et al. Hemolysis at different vacuum levels during vacuumassisted venous drainage: a prospective randomized clinical trial. Thorac Cardiovasc Surg 2012;60:262-8.

18. Nygaard K, Thiara AS, Tronstad C, et al. VAVD vacuum may cause bubble transgression in membrane oxygenators. Perfusion 2016. [Epub ahead of print].

19. Corno AF. Systemic venous drainage: can we help Newton? Eur J Cardiothorac Surg 2007;31:1044-51.

20. Potger KC, McMillan D, Ambrose M. Microbubble transmission during cardiotomy infusion of a hardshell venous reservoir with integrated cardiotomy versus a softshell venous reservoir with separated cardiotomy: an in vitro comparison. J Extra Corpor Technol 2013;45:77-85.

21. Senders JW. On the complexity of medical devices and systems. Qual Saf Health Care 2006;15:141-3.

22. Anastasiadis K, Murkin J, Antonitsis P, et al. Use of minimal invasive extracorporeal circulation in cardiac surgery: principles, definitions and potential benefits. A position paper from the Minimal invasive Extra-Corporeal Technologies international Society (MiECTiS). Interact Cardiovasc Thorac Surg 2016;22:647-62.

23. Anastasiadis K, Antonitsis P, Argiriadou H, et al. Modular minimally invasive extracorporeal circulation systems; can they become the standard practice for performing cardiac surgery? Perfusion 2015;30:195-200.

24. Anastasiadis K, Antonitsis P. MICS - MiECC: Can't have one without the other. Perfusion 2016;31:438-9.

25. Anastasiadis K, Antonitsis P, Deliopoulos A, et al. A multidisciplinary perioperative strategy for attaining "more physiologic" cardiac surgery. Perfusion 2017;32:446-53.

26. Abdel Aal M, ElNahal N, Bakir BM, et al. Minicardiopulmonary bypass impact on blood conservation strategy in coronary artery bypass grafting. Interact Cardiovasc Thorac Surg 2011;12:600-4.

27. Abdel-Rahman U, Martens S, Risteski P, et al. The use of minimized extracorporeal circulation system has a beneficial effect on hemostasis--a randomized clinical study. Heart Surg Forum 2006;9:E543-8.

28. Abdel-Rahman U, Ozaslan F, Risteski PS, et al. Initial experience with a minimized extracorporeal bypass system: is there a clinical benefit? Ann Thorac Surg 2005;80:238-43.

29. Bauer A, Diez C, Schubel J, et al. Evaluation of hemodynamic and regional tissue perfusion effects of minimized extracorporeal circulation (MECC). J Extra Corpor Technol 2010;42:30-9.

30. Bauer A, Hausmann H, Schaarschmidt J, et al. Shedblood-separation and cell-saver: an integral Part of MiECC? Shed-blood-separation and its influence on the perioperative inflammatory response during coronary revascularization with minimal invasive extracorporeal circulation systems - a randomized controlled trial. Perfusion 2018;33:136-47.

31. Huybregts RA, Morariu AM, Rakhorst G, et al. Attenuated renal and intestinal injury after use of a minicardiopulmonary bypass system. Ann Thorac Surg 2007;83:1760-6.

32. Wiesenack C, Liebold A, Philipp A, et al. Four years' experience with a miniaturized extracorporeal circulation system and its influence on clinical outcome. Artif Organs 2004;28:1082-8.

33. Anastasiadis K, Antonitsis P, Asteriou C, et al. Quantification of Operational Learning in Minimal Invasive Extracorporeal Circulation. Artif Organs 2017;41:628-36.

34. Ganushchak YM, Severdija EE, Simons AP, et al. Can minimized cardiopulmonary bypass systems be safer? Perfusion 2012;27:176-82.

35. Ganushchak YM, Korver EP, Yamamoto Y, et al. Versatile minimized system - a step towards safe perfusion. Perfusion 2015;31 295-9.

36. Fernandes P, MacDonald J, Cleland A, et al. The use of a mini bypass circuit for minimally invasive mitral valve surgery. Perfusion 2009;24:163-8.

37. Ito T. Minimally invasive mitral valve surgery through right mini-thoracotomy: recommendations for good exposure, stable cardiopulmonary bypass, and secure myocardial protection. Gen Thorac Cardiovasc Surg 2015;63:371-8.

38. Barbero C, Ricci D, El Qarra S, et al. Aortic cannulation system for minimally invasive mitral valve surgery. $\mathrm{J}$ Thorac Cardiovasc Surg 2015;149:1669-72.

39. Chan EY, Lumbao DM, Iribarne A, et al. Evolution of cannulation techniques for minimally invasive cardiac 
surgery: a 10-year journey. Innovations (Phila) 2012;7:9-14.

40. Lamelas J, Williams RF, Mawad M, et al. Complications Associated With Femoral Cannulation During Minimally Invasive Cardiac Surgery. Ann Thorac Surg 2017;103:1927-32.

41. Moschovas A, Amorim PA, Nold M, et al. Percutaneous cannulation for cardiopulmonary bypass in minimally invasive surgery is associated with reduced groin complications. Interact Cardiovasc Thorac Surg 2017;25:377-83.

42. Murzi M, Glauber M. Central versus femoral cannulation during minimally invasive aortic valve replacement. Annals of Cardiothoracic Surgery 2014;4:59-61.

43. Pozzi M, Henaine R, Grinberg D, et al. Total percutaneous femoral vessels cannulation for minimally invasive mitral valve surgery. Annals of Cardiothoracic Surgery 2013;2:739-43.

44. Ramchandani M, Al Jabbari O, Abu Saleh WK, et al. Cannulation Strategies and Pitfalls in Minimally Invasive Cardiac Surgery. Methodist DeBakey Cardiovascular Journal 2016;12:10-3.

45. Rosu C, Bouchard D, Pellerin M, et al. 401 Predictors of Need for Modified Femoral Arterial Cannulation During Minimally-Invasive Mitral Valve Surgery With Endoaortic Occlusion. Can J Cardiol 2012;28:S250.

46. Vercaemst L. Hemolysis in cardiac surgery patients undergoing cardiopulmonary bypass: a review in search of a treatment algorithm. J Extra Corpor Technol 2008;40:257-67.

47. Kameneva MV, Burgreen GW, Kono K, et al. Effects of turbulent stresses upon mechanical hemolysis: experimental and computational analysis. ASAIO J 2004;50:418-23.

48. Vermeulen Windsant IC, de Wit NC, Sertorio JT, et al. Hemolysis during cardiac surgery is associated with increased intravascular nitric oxide consumption and perioperative kidney and intestinal tissue damage. Front Physiol 2014;5:340.

49. Simons AP, Martens EG, Ganushchak YM, et al. Centrifugal pump performance during low-flow extracorporeal CO2 removal; safety considerations. Perfusion 2015;30:17-23.

50. Simons AP, Ganushchak YM, Teerenstra S, et al. Hypovolemia in extracorporeal life support can lead to arterial gaseous microemboli. Artif Organs 2013;37:276-82.

51. Iserson KV. The origins of the gauge system for medical equipment. J Emerg Med 1987;5:45-8.

52. Kohler K, Valchanov K, Nias G, et al. ECMO cannula review. Perfusion 2013;28:114-24.

53. Delius RE, Montoya JP, Merz SI, et al. New method for describing the performance of cardiac surgery cannulas.
Ann Thorac Surg 1992;53:278-81.

54. Montoya JP, Merz SI, Bartlett RH. A standardized system for describing flow/pressure relationships in vascular access devices. ASAIO Trans 1991;37:4-8.

55. De Somer F. Strategies for optimisation of paediatric cardiopulmonary bypass. University of Groningen; 2003. Available online: https://www.rug.nl/research/portal/en/ publications/strategies-for-optimisation-of-paediatriccardiopulmonary-bypass\% 2857f70c89-00b6-4f6a-bcfebce 5c591eec2\%29.html

56. De Wachter D, De Somer F, Verdonck P. Hemodynamic comparison of two different pediatric aortic cannulas. Int J Artif Organs 2002;25:867-74.

57. Jones RT. Blood Flow. Annual Review of Fluid Mechanics 1969;1:223:44.

58. Verdonck PR, Siller U, De Wachter DS, et al. Hydrodynamical comparison of aortic arch cannulae. Int J Artif Organs 1998;21:705-13.

59. Rosu C, Bouchard D, Pellerin M, et al. Preoperative vascular imaging for predicting intraoperative modification of peripheral arterial cannulation during minimally invasive mitral valve surgery. Innovations (Phila) 2015;10:39-43.

60. Heuts S, Daemen JHT, Streukens SAF, et al. Preoperative Planning of Transapical Beating Heart Mitral Valve Repair for Safe Adaptation in Clinical Practice. Innovations (Phila) 2018;13:200-6.

61. Oakes DA, Mangano CT. Cardiopulmonary bypass in 2009: achieving and circulating best practices. Anesth Analg 2009;108:1368-70.

62. Brittain EL, Goyal SK, Sample MA, et al. Minimally invasive fibrillating mitral valve replacement for patients with advanced cardiomyopathy: a safe and effective approach to treat a complex problem. J Thorac Cardiovasc Surg 2014;148:2045-51.e1.

63. Kilo J, Ruttmann-Ulmer E, Grimm M, et al. Minimally invasive mitral valve reconstruction on the fibrillating heart for high-risk patients. J Heart Valve Dis 2013;22:665-8.

64. Loulmet DF, Patel NC, Jennings JM, et al. Less invasive intracardiac surgery performed without aortic clamping. Ann Thorac Surg 2008;85:1551-5.

65. Massimiano PS, Yanagawa B, Henry L, et al. Minimally invasive fibrillating heart surgery: a safe and effective approach for mitral valve and surgical ablation for atrial fibrillation. Ann Thorac Surg 2013;96:520-7.

66. Ad N, Holmes SD, Shuman DJ, et al. Minimally invasive mitral valve surgery without aortic cross-clamping and with femoral cannulation is not associated with increased risk of stroke compared with traditional mitral valve 
surgery: a propensity score-matched analysis. Eur J Cardiothorac Surg 2015;48:868-72; discussion 872.

67. Romano MA, Haft JW, Pagani FD, et al. Beating heart surgery via right thoracotomy for reoperative mitral valve surgery: a safe and effective operative alternative. J Thorac Cardiovasc Surg 2012;144:334-9.

68. Xu RB, Rahnavardi M, Nadal M, et al. Beating heart minimally invasive mitral valve surgery in patients with previous sternotomy: the operative technique and early

doi: 10.21037/jovs.2018.12.04

Cite this article as: Ganushchak Y, Sardari Nia P. Perfusion techniques in minimally invasive setting. J Vis Surg 2018;4:250. outcomes. Open Heart 2018;5:e000749.

69. Merry AF, Weller J, Mitchell SJ. Teamwork, communication, formula-one racing and the outcomes of cardiac surgery. J Extra Corpor Technol 2014;46:7-14.

70. Endsley MR. Towards a theory of Situtation awareness in dynamic systems. Human factors 1995;37:32-64.

71. Ganushchak YM, Weerwind PW, Maessen JG. A glance to the future. Perfusion 2012;27:95-6. 